DOI 10.18551/rjoas.2019-02.13

\title{
CONSTRUCTION OF COLLABORATIVE GOVERNANCE MODEL OF INDONESIAN OVERSEAS GRADUATE STUDY SCHOLARSHIP PROGRAM
}

\author{
Ridwan*, Wijaya Chandra, Kasim Azhar \\ Department of Public Administration, Faculty of Administrative Sciences, \\ University of Indonesia, Indonesia \\ *E-mail: ridwananzib123@gmail.com
}

\begin{abstract}
The aim of this paper is to construct collaborative governance model of the Indonesian Overseas Graduate Study Scholarship Program (IOGSSP) managed by the Directorate General of Higher Education at the Ministry of Education and Culture of the Republic of Indonesia. Using the framework of Ansell \& Gash (2007), this paper aligns the strategic plan of IOGSSP with the strategic plan of Talent Management of University Lecturers (TMUL). This alignment is a precondition (critical variable) in constructing the model.
\end{abstract}

\section{KEY WORDS}

Overseas graduate study, scholarship program, collaborative governance, strategic plan, talent management, soft systems methodology, action research.

IOGSSP is currently growing rapidly and competitively, involving an ever-increasing and unprecedented number of students. The program encourages student and faculty collaboration across international borders, creating human capital in developing countries. Higher education scholarship programs encourage countries and individuals to build capacity and alleviate poverty (Turner \& Robson in Medica, 2010).

The Government of Indonesia through the Directorate General of Higher Education of the Ministry of Education and Culture since 2008 seeks to enhance academic qualifications of university lecturers by providing overseas postgraduate scholarships funded through State budgets, especially at Doctoral level. The number of recipients taking master and doctoral degrees abroad increased to 3,803 in 2012, across 27 countries (Kemdikbud, 2013).

The governance of IOGSSP tends to be hierarchical, authority-based, and marked by command and control (Yong-duck et al., 2009: 4). The challenge in addressing the issues of interconnectivity and inter-agency alignment in any program of governance (Nee, 2005) is to find common ground and to set goals through interactive, flexible, inclusive, non-hierarchical cooperation between all those involved. Communication barriers, conflict, lack of commitment, proud stakeholders each with their own motivation and goals, and no roadmap of the intentions of the program regrettably characterise program governance managed by authority-based mechanisms (http://studi.dikti.go.id/forum).

Surveys by the Program Overseas Students Association (POSA) reveal multiple problems. Due to the limited human resources of the office of IOGSSP, failures of communication lead to suspicion and distrust between scholarship recipients and the program managers (Kemdikbud, 2013).

The lack of commitment of stakeholders reveals itself in late payment of scholarship funds. In order for payments to flow smoothly, each party must perform their duties and meet their obligations (Kemdikbud, 2013). Any disbursement of government money requires a certain time and bureaucracy process. IOGSSP funds come from the State Revenue Budget, which is a component of the budget of the Directorate General of Higher Education, and complete documentation is required for the audit trail (Kemdikbud, 2013).

Each university's strategic plan depends on the lecturers' availability, requirements, and existing expertise. The strategic plan of IOGSSP must align with that of TMUL as well (Kemdikbud, 2013). Talent management says Riccio (2010: 1) will greatly help in planning, in recruiting lecturers, in improving their quality, and in advancing their careers. 
The purpose of this research is to construct collaborative governance model of IOGSSP through alignment of its strategic plan with the strategic plan of TMUL, improvement of communication as well as commitment among the program stakeholders.

\section{LITERATURE REVIEW}

Collaborative Governance. Collaboration, the noun, is working (Latin labor) together (Latin co-) across organizational boundaries in multi-sectoral relationships to achieve a common goal, while to govern, the verb, is "to direct processes to influence decisions and actions within the public, private, and civil sectors" (Eppel, 2013: 27).

Lynn, Heinrich, \& Hill (2001: 7) in Ansell \& Gash (2007: 545) interpret governance as "the legal regimes, rules, judicial precedents, and administrative practices that limit, regulate, and enable the provision of public goods and services." Stoker (2004: 3) in Ansell \& Gash (2007: 545) defines it as "the rules and ordinances that direct collective decision-making"; governance, they say, is not about an individual making decisions but rather about organizations operating a system.

Collaborative governance involves people constructively across borders to implement a public goal (Emerson, Nabatchi \& Balogh, 2011). It is also defined as an arrangement whereby one or more public agencies directly engage non-state stakeholders in a collective decision-making process that is formal, consensus-oriented, and deliberative and that aims to make or implement public policy or manage public programs or assets (Ansell \& Gash, 2007). Figure 1 below shows their model.

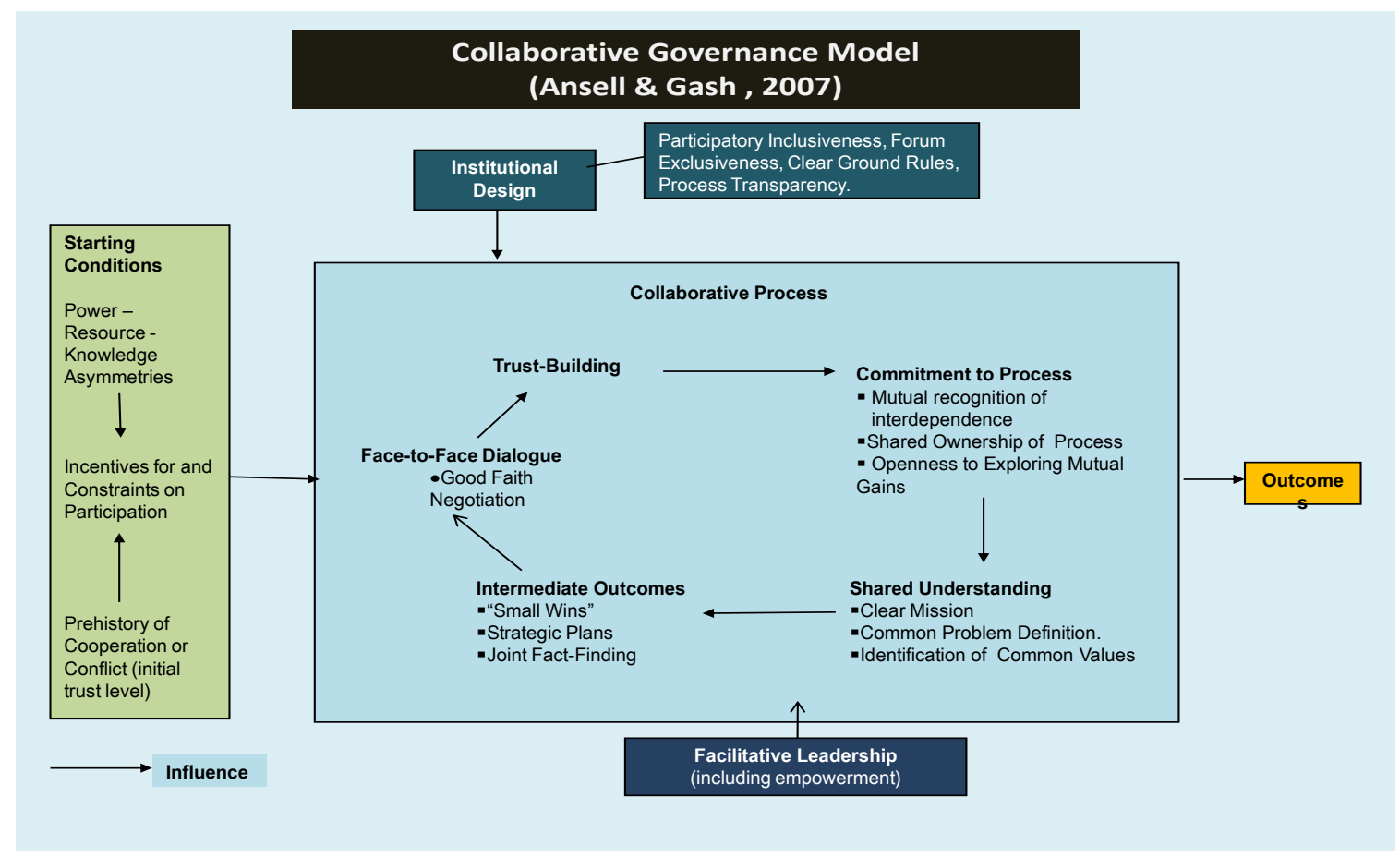

Figure 1 - Collaborative Governance Model (Ansell \& Gash, 2007)

Four variables make up the model, namely (1) the starting conditions, (2) the institutional design, (3) the leadership, and (4) the collaborative process, where process variables form the core of the model. Initial conditions, institutional design, and leadership variables contribute either as critical determinants or as contextualizes (Ansell \& Gash, 2007).

Collaboration is a gradual process. Susskind \& Cruikshank (1987: 95) describe a consensus-building process: the pre negotiation phase, the negotiation phase, and the implementation phase. Gray (1989) also defines three steps of a collaboration process: (1) problem setting, (2) directional setting, and (3) implementation. Again, Edelenbos (2005: 
118) identifies three steps - preparation, policy development, and decision making - with each step having several stages. Ansell \& Gash conclude that collaborative processes are non-linear and cyclic, and progress depends on communication, trust, commitment, understanding, and positive outcomes for reinforcement (Huxham 2003; Imperial 2005 in Ansell \& Gash, 2007: 55).

Lack of communication and coordination between stakeholders and between internal departments and offices can lead to wasteful duplication, unmet needs, ill-feeling, conflict, and reduced synergy. On a more positive note, dialogue between stakeholders is intended to open communication channels, facilitate shared vision, and elicit positive feedback on the evolving programs, services, and decisions (Catmur, A, 2008). In collaborative governance it is very important to pay attention to communication, for example by arranging meetings in which each person takes a turn as facilitator. Communication may be face-to-face or by electronic means like email or telephone. Some internet video communications are themselves face-to-face to a certain extent. Thus, the meeting agenda can be led by the place and type of communication process used. Agreement on purpose, shared vision, communication, accountability, the existence of user communities, individual capabilities, and clarity of governance arrangements are key factors of successful collaboration (O'Flynn, J. \& Wanna, J., 2008).

All Collaborative Governance practices are built on face-to-face dialogue to identify what opportunities are mutually beneficial to the stakeholders. Face-to-face dialogue is more than just a negotiating medium and is at the heart of the stereotypical liquefaction process and other barriers to communicate and prevent any joint profit exploration (Bentrup 2001). Face-to-face dialogue is at the heart of the process of building trust, mutual respect, mutual understanding, and commitment to processes (Gilliam et al., 2002; Lasker \& Weiss 2003; Plummer \& Fitzgibbon 2004; Schneider et al., 2003; Tompkins \& Adger 2004; 2006; in Ansell \& Gash, 2007: 558).

Lack of trust is the spur to collaborative governance at all (Weech-Maldonado \& Merrill, 2000 in Ansell \& Gash, 2007: 558), but the process must immediately foster and continue to build trust among stakeholders (Alexander, Comfort, \& Weiner, 1998; Beierle \& Konisky, 2001; Brinkerhoff, 1999; Glasbergen \& Driessen, 2005; Imperial, 2005; Murdock, Wiessner, \& Sexton, 2005; Tett, Crowther, \& O'Hara, 2003; Vangen \& Huxham, 2003b in Ansell \& Gash, 2007: 558-559). When there is historical antagonism, building trust is crucial and often very difficult (Murdock, Wiessner, and Sexton 2005 in Ansell and Gash, 2007: 558-559).

Although the terminology varies in Ansell \& Gash (2007: 559), it is clear that on the level of stakeholder commitment depends the ultimate success or failure of the collaboration. Commitment mirrors genuine motivation to participate in collaborative governance. Of course, some stakeholders participate initially just to ensure that their perspectives are not overlooked, to secure the legitimacy of their position, to fulfil legal obligations, and for other subjective considerations. Burger et al. (2001) in Ansell \& Gash (2007: 559) explain that true commitment comes from realising - perhaps only after a cycle or two of negotiations - that the goodwill of bargaining for mutual benefit is the best way to achieve it.

At some point of the collaborative process, stakeholders develop a shared understanding of what they can achieve collectively. This is described as "sharing the same mission" (Alexander, Comfort, \& Weiner, 1998; Roussos \& Fawcett, 2000), as "commonality" (Wondolleck \& Yaffee 2000), as "common goals" ( Walter \& Petr, 2000; Wondolleck \& Yaffee 2000), as "common ideology" (Waage, 2001), as "the common vision" (Mana \& Pearsall, 2004; Walter \& Petr, 2000; Glasbergen \& Driessen, 2005; Roberston \& Lawes, 2005), as "clear and strategic directions" (Margerum, 2002), and as "core values alignment" (Heikkilä and Gerlak, 2005).

Collaboration is more likely to occur (a) when goals are likely to be achieved, and (b) when the benefits of collaboration are relatively achievable, and (c) when small wins of collaboration accrue quickly. Although intermediate outcomes may show real benefit, the critical process is cyclic, and reiterated outcomes build the momentum of success. "Little victories" encourage subsequent cycles to build trust and commitment (Rogers et al., 1993; Vangen \& Huxham, 2003b in Ansell \& Gash, 2007: 561). 
The Concept of Alignment. Skinner (1974) speaks of strategic consensus, Porter (1996) and Venkatraman (1989) refer to it as fit, and Henderson \& Venkatraman (1993) use alignment. Each of these phrases encompasses a concept of alignment. According to Porter (1996), strategy means making the activities of an organization fit each other. In other words, activities must cooperate and support and strengthen each other. Boyer \& McDermott (1999; in Salimian, H., et. al., 2012) state that strategic alignment means that individuals at various organizational levels agree on the issues of cost, quality, delivery and flexibility, all of which are important for success.

Other writers agree (Hayes \& Wheelwright, 1984; Hill, 1988; Voss, 2005). According to Venkatraman (1989), six types of alignment are possible in two dimensions: (1) relating alignment to a specific criterion, and (2) the degree of accuracy in forming alignment relationships. The model assumes that the greater the number of equation variables, the lower the degree of accuracy in alignment relations will be. In the viewpoint of alignment which considers it as a moderator, the effect of an independent variable (such as strategy) on a dependent variable (such as performance) depends on another variable (such as environment) which is known as the moderator. In the alignment approach as mediation, a variable such as organizational structure affects the relationship between a primary variable (such as strategy) and a consequent variable (such as performance). The alignment approach expresses coordination between two variables.

What distinguishes this approach from previous approaches is that in this approach, a criterion variable such as performance is not considered. Nevertheless, even in this approach the effect of coordination of two variables on one or more criterion variables selected by the researcher is measured. A famous example of this approach is Chandler's study on the relationship between structure and strategy. Two dimensions appear alignment of the strategy of functional units and business strategy (vertical alignment), and alignment of functions (horizontal alignment). Functional strategies shape the business-level strategy; in the words of Beckman \& Rosenfield (2008), decisions made at functional units become the business strategy. A window of alignment can be defined whose panes comprise the functional strategies and whose frame is the business strategy. From this we conclude that functional strategies provide necessary elements for gaining competitive advantage. However, each unit pursues its own strategy, and each unit's strategy must fit with the strategies of other units as well as with the business-level strategy. Fitness of small windows with one another is defined as horizontal alignment and fitness of small windows with the window frame is defined as vertical alignment. Alignment enhances performance and misalignment degrades performance (Salimian, H., et. al., 2012).

\section{METHODS OF RESEARCH}

We use a Soft Systems Methodology (SSM), as is appropriate for a study looking at the world as a complex, problematic, mysterious theatre, characterized by opposing viewpoints and clashes of Weltanschauung (world view) (Checkland \& Poulter, 2006; Checkland, 1981). SSM facilitates experience-based knowledge (Checkland and Scholes, 1990), moving between reality (or perceived reality) and subjective actuality, that is, feelings about the real world (Uchiyama, 1999). In our case, reality is the Indonesian overseas graduate study scholarship program (IOGSSP).

A researcher declares their theoretical framework $(F)$ and method $(M)$ used to formulate and guide their study (Checkland, 1991). A reflection of the $F, M, A$, or the theme of the research should be made to the invention of the results achieved. In the end, the design cycle and problem-solving research interest - as in this study, will give birth to new knowledge, modifying the questions that have been there, or get a new question be produced at $\mathrm{A}$ or $\mathrm{F}$.

We gather data in accordance with the seven-stage principle of SSM. Results at an early stage are realized in the form of a Rich Picture (Checkland \& Scholes, 1990).

The seven stages appear in Figure 2 above. Those are (1) finding an unstructured problem, (2) determining the structure of the problem, (3) making root definitions of relevant 
systems, (4) developing conceptual models, (5) comparing conceptual models with structured problem situations, that is, comparing stage 2 and stage 4, (6) considering feasible changes acceptable to stakeholders, and (7) taking action to improve the situation.

Table 1 - Research Framework

\begin{tabular}{|l|l|}
\hline $\mathrm{n} / \mathrm{n}$ & Explanation \\
\hline $\mathrm{F}$ & Collaborative governance (Ansell \& Gash, 2007) \\
\hline MPS & Action Research Methodology - Soft Systems Methodology \\
\hline $\mathrm{P}$ & Construction of collaborative governance model of IOGSSP \\
\hline
\end{tabular}

Source: Adapted from McKay \& Marshall (2001).

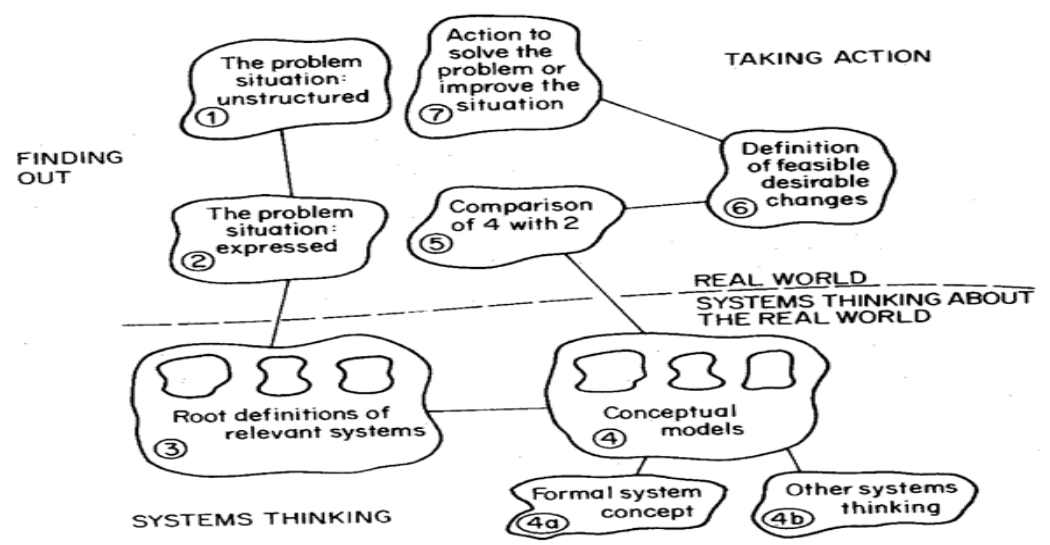

Figure 2 - Framework of SSM (Source: Checkland \& Poulter, 2006)

Our data collection follows Checkland \& Poulter (2006; in Hardjosoekarto 2012). Their approach is: 1) an informal talk, 2) reading documents, 3) chairing meetings, 4) conducting interviews, and 5) hosting informal "tea parties" or similar social events, while simultaneously taking note of all things related to roles (actual and assumed), norms (societal and individual), and values (again, both societal and personal). Primary data is collected at deep interviews, through focus group discussions, and by observation. Secondary data comes from the literature and related documents. Deep interviewees include: 1) lecturers or working student candidates, program participants (working students), and program alumni (graduates), and 2) Indonesian overseas graduate study scholarship program managers at native (home) universities, and 3) policy makers in native universities (for example related Vice Rectors), and 4) representatives of Ditjen Dikti, the top-level of IOGSSP management, and 5) relevant parties at the destination (host) universities abroad (supervisors and international student officers).

\section{RESULTS OF STUDY}

As we show in detail below, in this research, we act along with the promoter and copromoter (academic advisors) in order to align the strategic plan of IOGSSP with the strategic plan of TMUL.

Stage One - The Problem Situation Unstructured. Three problems present themselves: 1) misalignment of the strategic plan of IOGSSP with the strategic plan of TMUL (planning, recruitment and career development of lecturers), 2) miscommunication among stakeholders (face-to-face dialogue, and trust building being faulty or entirely absent), and 3) isolation of stakeholders (no commitment to process, no shared understandings, and no dialogue).

Stage Two - The Problem Situation Expressed. The second stage of the SSM uses three analyses. Analysis one is of intervention (clients, practitioners and problem owners of the issues addressed), Analysis Two is of social roles, norms, and values, and Analysis Three is wholly political. The Rich Picture of collaborative governance of IOGSSP makes up Figure 3 below. 


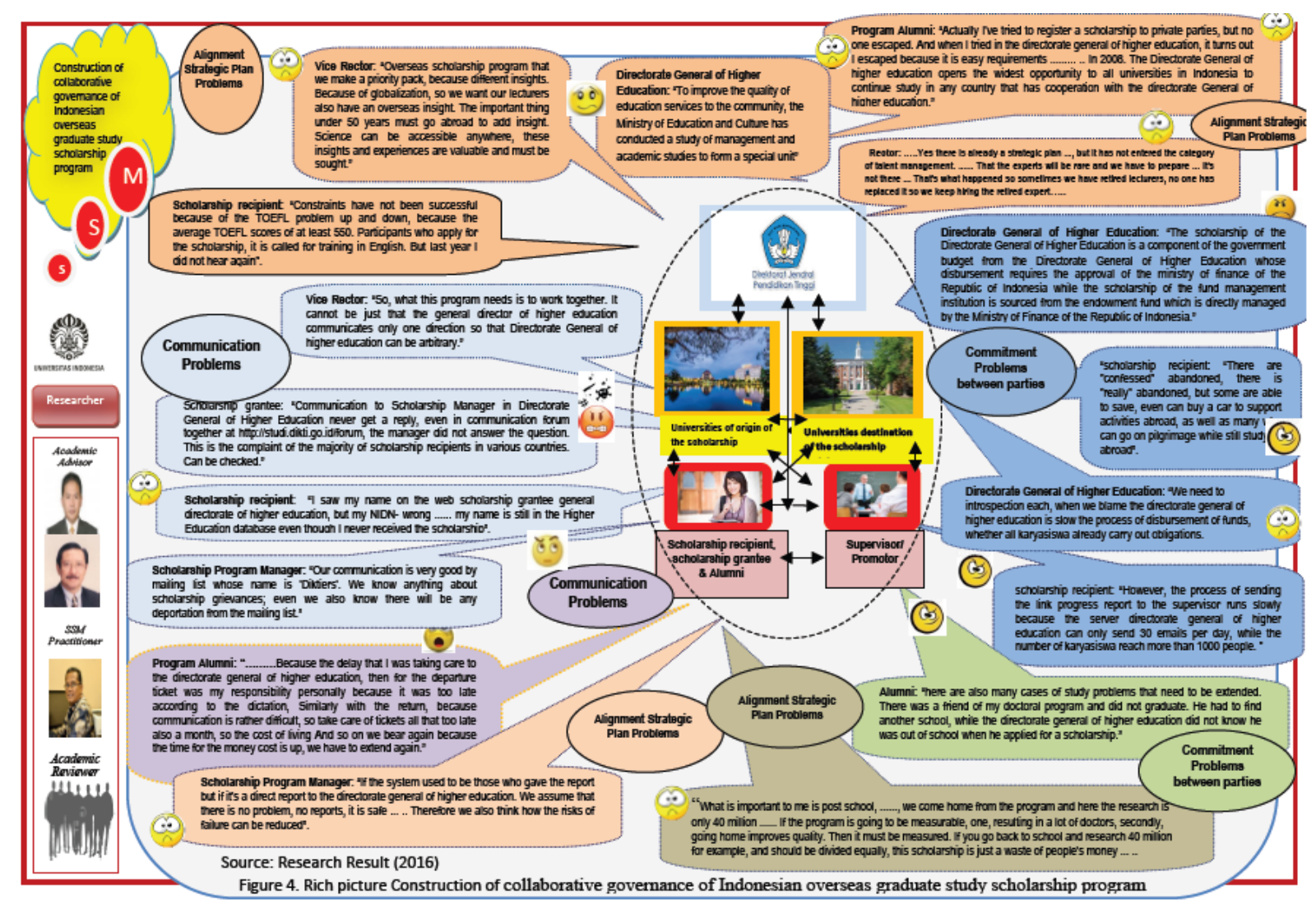

Figure 3 - Rich Picture Source: Research Result (2016)

Stage Three - The Development of a Root Definition from the Rich Picture. The Root Definition (RD) to construct the conceptual model of IOGSSP is "The system owned and operated by researchers and promoters and co-promoters (academic advisors) to explore the alignment of the strategic plan of IOGSSP with strategic plan of TMUL, stakeholder communication, and stakeholder commitment $(P)$ using Soft Systems Methodology approach $(Q)$ in order to construct models of overseas governance study scholarship program (R)."

To construct a conceptual model of IOGSSP we used CATWOE Analysis (Checkland, 1990: 70) as shown in Table 2 following:

Table 2 - CATWOE Root Definition

\begin{tabular}{|c|c|}
\hline Customers & $\begin{array}{l}\text { ndidates for scholarships, scholarship recipients, alumni of the program, home universities, } \\
\text { st universities, and student supervisors. }\end{array}$ \\
\hline Acto & eral of Higher Education, scholarship recipients, universities and supervisors. \\
\hline $\begin{array}{l}\text { Tran } \\
\text { Proc }\end{array}$ & $\begin{array}{l}\text { on becomes the output of IOGSSP process - from being antagonistic to } \\
\text { borative }\end{array}$ \\
\hline World view & of transformation of better IOGSSP so as to achieve the program strategic \\
\hline 0 & \\
\hline $\begin{array}{l}\text { En } \\
\text { con }\end{array}$ & $\begin{array}{l}\text { Higher Education and outside it. } \\
\text { Time constraints in the form of deadlines to complete the doctoral program. } \\
\text { Possible changes in policy at the Directorate General of Higher Education. }\end{array}$ \\
\hline
\end{tabular}

Source: Research Result (2015).

Stage Four - Conceptual Models. In accordance with the system which has been named in the RD, a Conceptual Model of IOGSSP was created. Conceptual Model Construction refers to CATWOE and is analyzed according to the 3E criteria (Efficacy, Efficiency, and Effectiveness) related to three important elements: input, transformations, and output to assess the reliability of the conceptual model. The model includes processes 
by which the actors can work together to achieve the objectives, that is, that IOGSSP should produce overseas universities doctoral programs on time as well as earn respect at an international level.

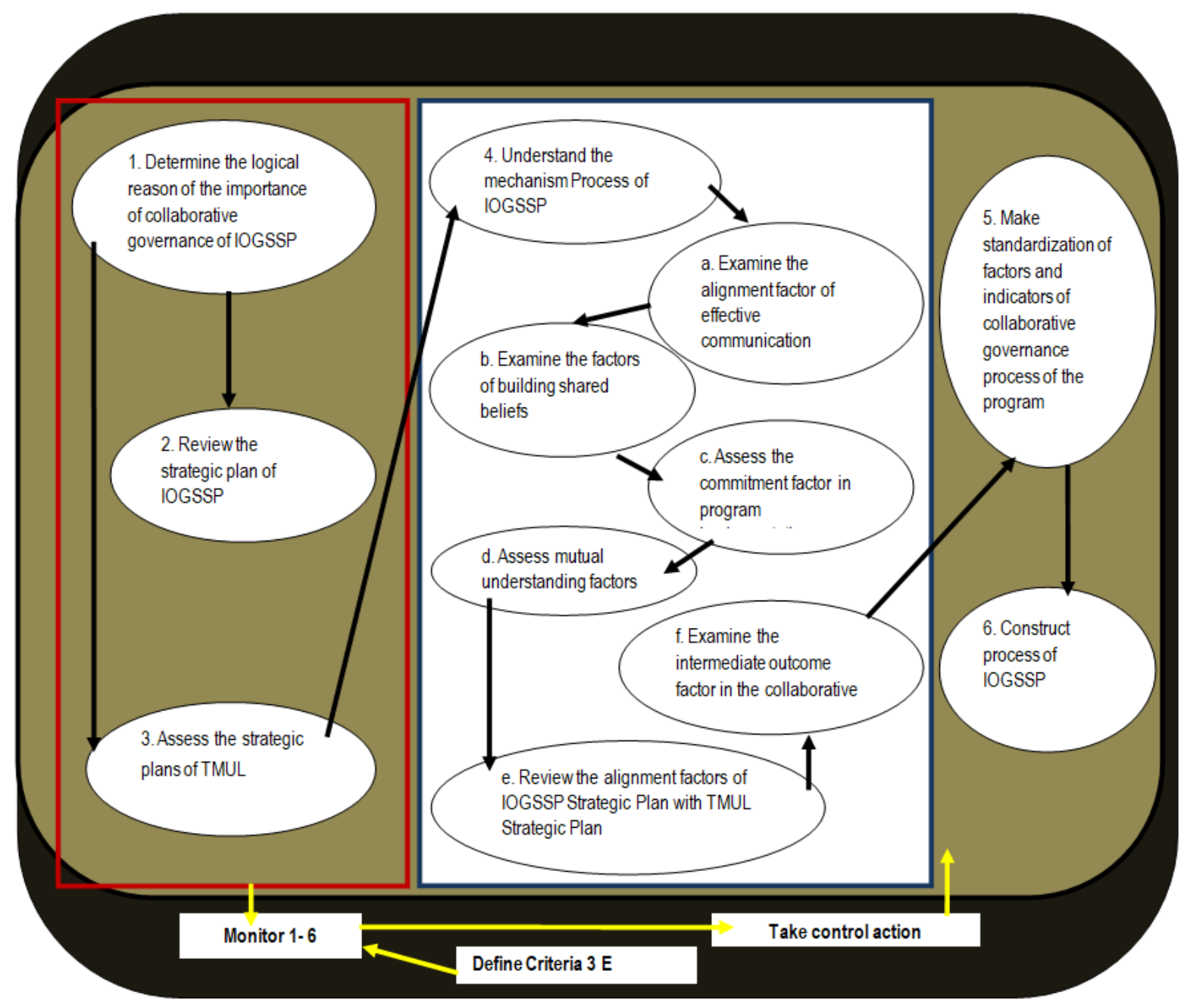

Figure 4 - Conceptual Model of IOGSSP (Source: Research Result, 2016)

Stage 5 - Comparison of the Conceptual Model with Real World (Perceived Reality). We compare conceptual models with the real world by creating Table 3 below, consisting of conceptual model activity, its presence in reality, and comments. The results of this SSM fifth stage analysis form the basis for determining changes in the collaborative governance model (Ansell \& Gash 2007).

Stage Six - Systemically Desirable and Culturally Feasible Changes. The results from stage five lead naturally into discussions of the future. There are various ways to proceed at this stage. One way, for example, is to have a structured discussion with everyone involved, leading to agreement on changes which are both systemically feasible and culturally acceptable, possibly even desirable.

Already we obtain a clear picture through group discussions, interviews, direct observations, and notes taken at each of the campuses and stakeholders visited - a picture of ineffective and inefficient communication, lack of commitment, misalignment, and ill feeling. All agree that these challenges require resolution: the Directorate General of Higher Education, scholarship recipients, home universities, destination universities, student supervisors, and the students themselves. 
Table 3 - Comparison of the Conceptual Model with Real World

\begin{tabular}{|c|c|c|c|}
\hline No. & Activities in conceptual model & Presence in real world situation & Comments \\
\hline 1 & $\begin{array}{l}\text { Determine the logical reason } \\
\text { for the importance of } \\
\text { collaborative governance of } \\
\text { IOGSSP }\end{array}$ & $\begin{array}{l}\text { Ineffective and inefficient communication } \\
\text { among stakeholders; } \\
\text { Lack of commitment among } \\
\text { stakeholders or actors; } \\
\text { The strategic plan of IOGSSP has not } \\
\text { been aligned with that of TUML. }\end{array}$ & $\begin{array}{l}\text { The need for improved communication, } \\
\text { stakeholder commitment and alignment of } \\
\text { IOGSSP strategic plan with TMUL } \\
\text { strategic plan. }\end{array}$ \\
\hline 2 & $\begin{array}{l}\text { Review the Strategic Plan of } \\
\text { IOGSSP }\end{array}$ & $\begin{array}{l}\text { No national human resource } \\
\text { development plan yet exists; } \\
\text { There is no strategic plan for the } \\
\text { resources of the Ministry's lecturers; } \\
\text { No strategic plan of the program yet } \\
\text { exists. }\end{array}$ & $\begin{array}{l}\text { We need a national human resource } \\
\text { development plan. }\end{array}$ \\
\hline 3 & $\begin{array}{l}\text { Assess the Strategic Plan of } \\
\text { TMUL }\end{array}$ & There is no strategic plan for TMUL & We need a strategic plan for TMUL. \\
\hline 4 & $\begin{array}{l}\text { Understand the mechanism of } \\
\text { governance of IOGSSP }\end{array}$ & $\begin{array}{l}\text { Poor communication among } \\
\text { stakeholders; } \\
\text { Mistrust in IOGSSP management; } \\
\text { Lack of commitment ; } \\
\text { Frequent misunderstandings; } \\
\text { Misalignment of IOGSSP strategic plan } \\
\text { with TMUL strategic plan }\end{array}$ & $\begin{array}{l}\text { We need to establish communication } \\
\text { among stakeholders; } \\
\text { We need to build mutual trust in } \\
\text { management; } \\
\text { We need commitment to the program; } \\
\text { We need to build mutual understanding ; } \\
\text { We need alignment between IOGSSP } \\
\text { strategy and that of TMUL. }\end{array}$ \\
\hline 4.a. & $\begin{array}{l}\text { Examine the alignment factor } \\
\text { of effective communication } \\
\text { among stakeholders }\end{array}$ & $\begin{array}{l}\text { Unreliable IT systems (websites, forums, } \\
\text { mailing lists, and e-mail); } \\
\text { Ineffective use of IT systems; } \\
\text { Mismanagement of records and } \\
\text { incomplete documentation; } \\
\text { Ineffective face-to-face meetings and } \\
\text { pointless dialogue; } \\
\text { The absence of a common } \\
\text { understanding of work. }\end{array}$ & $\begin{array}{l}\text { The need for improvement of information } \\
\text { technology governance system programs } \\
\text { (websites, forum mailing lists, and e-mail); } \\
\text { The need for improvement of online } \\
\text { communication (information technology- } \\
\text { based communication); } \\
\text { The need for improved archive } \\
\text { management and documentation; } \\
\text { The need for clarity in face-to-face } \\
\text { dialogue; } \\
\text { The need for mutually agreed goals. }\end{array}$ \\
\hline 4.b. & $\begin{array}{l}\text { Establish the level of mutual } \\
\text { trust in the governance of the } \\
\text { program }\end{array}$ & $\begin{array}{l}\text { Lack of mutual understanding of working } \\
\text { together }\end{array}$ & $\begin{array}{l}\text { The need to improve shared } \\
\text { understanding of work. }\end{array}$ \\
\hline 4.c & $\begin{array}{l}\text { Assess the commitment factor } \\
\text { in program implementation }\end{array}$ & $\begin{array}{l}\text { Lack of transparency in the process of } \\
\text { program delivery; } \\
\text { Lack of faith in mutual benefits; } \\
\text { Failure to comply with collective } \\
\text { agreements; } \\
\text { Lack of respect for the interests of each } \\
\text { stakeholder; } \\
\text { Lack of good faith in collective decision- } \\
\text { making ; } \\
\text { Lack of targeted responsibility } \\
\text { (accountability) for the process. }\end{array}$ & $\begin{array}{l}\text { The need for increased transparency in } \\
\text { the process of program delivery; } \\
\text { The need for faith in mutual benefits; } \\
\text { The need to improve compliance with } \\
\text { collective agreements; } \\
\text { The need to increase respect for the } \\
\text { interests of each stakeholder; } \\
\text { The need for good faith in collective } \\
\text { action; } \\
\text { The need for accountability for the } \\
\text { process. }\end{array}$ \\
\hline 4.d. & $\begin{array}{l}\text { Assess mutual understanding } \\
\text { factors in program } \\
\text { implementation }\end{array}$ & $\begin{array}{l}\text { The absence of clarity of program } \\
\text { mission } \\
\text { The absence of a common problem } \\
\text { definition } \\
\text { Lack of common values that want to be } \\
\text { developed. }\end{array}$ & $\begin{array}{l}\text { The need to clarify the mission of the } \\
\text { program } \\
\text { The need to define shared problems } \\
\text { The need to elicit common values. }\end{array}$ \\
\hline 4.e. & $\begin{array}{l}\text { Review alignment of IOGSSP } \\
\text { with TMUL }\end{array}$ & $\begin{array}{l}\text { Unsynchronized design and program } \\
\text { planning; } \\
\text { The strategy does not exist to achieve all } \\
\text { actors' objectives of IOGSSP; } \\
\text { Monitoring and evaluation are not yet } \\
\text { aligned with strategy. }\end{array}$ & $\begin{array}{l}\text { We must harmonize design and planning; } \\
\text { We must harmonize strategies to achieve } \\
\text { the shared goals of IOGSSP } \\
\text { stakeholders; } \\
\text { We must develop joint monitoring and } \\
\text { evaluation mechanisms. }\end{array}$ \\
\hline 4.f. & $\begin{array}{l}\text { Examine the intermediate } \\
\text { outcome factors that can drive } \\
\text { the collaborative process. }\end{array}$ & $\begin{array}{l}\text { Ineffective performance of boundary } \\
\text { spanners (individuals capable of carrying } \\
\text { out cross-border collaboration work); } \\
\text { Ineffective follow-up of monitoring and } \\
\text { evaluation (monev), and } \\
\text { Failure to share information and learning } \\
\text { opportunities. }\end{array}$ & $\begin{array}{l}\text { The need to improve the performance of } \\
\text { boundary spanners; } \\
\text { The need for follow-up of monitoring and } \\
\text { evaluation (monev), and } \\
\text { The need to generate mutual learning } \\
\text { between parties to solve common } \\
\text { problems. }\end{array}$ \\
\hline 5 & $\begin{array}{l}\text { Standardize factors and } \\
\text { indicators of the collaborative } \\
\text { governance process of } \\
\text { IOGSSP }\end{array}$ & $\begin{array}{l}\text { The lack of measurable indices of the } \\
\text { collaborative governance of IOGSSP }\end{array}$ & $\begin{array}{l}\text { The need to measure progress in } \\
\text { collaborative governance of IOGSSP }\end{array}$ \\
\hline 6. & $\begin{array}{l}\text { Construct a collaborative } \\
\text { governance model of IOGSSP. }\end{array}$ & $\begin{array}{l}\text { The absence of collaborative } \\
\text { governance of IOGSSP. }\end{array}$ & $\begin{array}{l}\text { The need for collaborative governance of } \\
\text { IOGSSP. }\end{array}$ \\
\hline
\end{tabular}




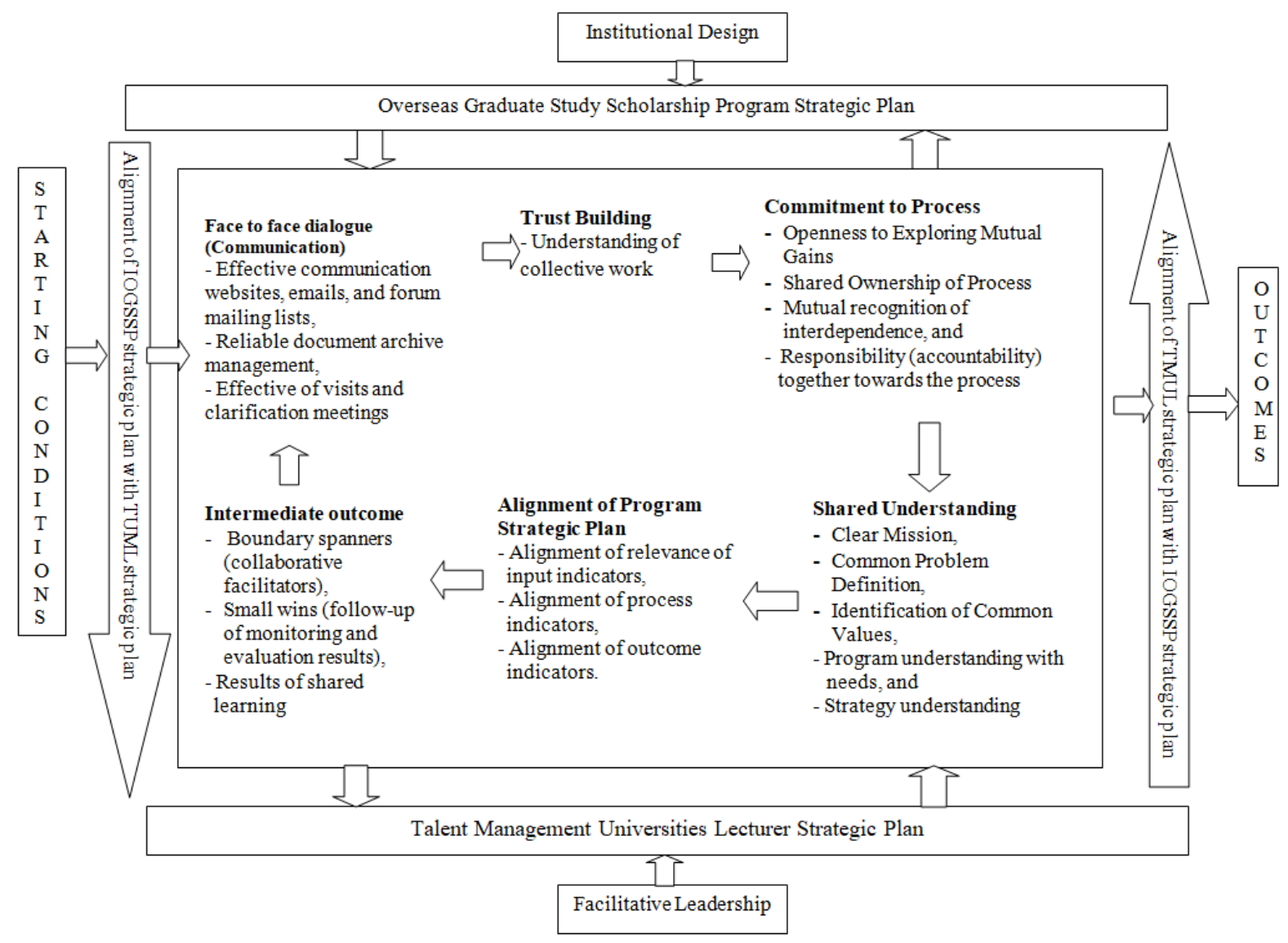

Figure 5 - Collaborative Governance Model of IOGSSP

Even before someone applies to IOGSPP, we find that only a few universities in Indonesia have a structured TMUL plan, and none necessarily observe the IOGSSP guidelines offered by the DGHE. So, in some cases the students' existing competencies and skills are not formally recognised, and their future study depends entirely upon their own judgement. Accordingly, we posit the alignment of IOGSSP and TMUL as a general variable of the model of collaborative governance.

\section{CONCLUSION AND RECOMMENDATIONS}

Using frameworks from Ansell \& Gash (2007) to construct our model of collaborative governance for IOGSSP reveals that their factors and indicators are not entirely sufficient. We propose an additional critical variable, that is, alignment of the strategic plan of IOGSSP with the strategic plan of TMUL. This alignment is a precondition for successful governance.

The standard process consists of:

- Communication (face to face dialogue, websites, e-mail, and forum mailing lists; management of document archives, visits and clarification meetings);

- Commitment (openness, shared ownership, interdependence, shared responsibility, trust, shared understanding, mission clarity, and equality of issues);

- The program's strategic alignment factors including alignment of input indicators, processes, outputs;

- Intermediate outcomes including collaborative facilitators, follow-up on monitoring and evaluation results, and joint learning outcomes.

As we explain above, it is necessary to modify the Ansell \& Gash collaborative model by adding a critical variable, that is, the alignment of IOGSSP with TMUL. Therefore we recommend a further in-depth study of the effectiveness of any collaborative governance model of IOGSSP. 
Practically, the collaborative governance model of IOGSSP can be used to assess the synergy of actors and institutions in the implementation of public policy in Indonesia. The results of the study can contribute and references to the Directorate General of Higher Education, scholarship Home University, scholarship Host University and can be used as a reference for reviewing collaborative governance on programs and other organizational activities.

\section{REFERENCES}

1. Alexander, Jeffery A., Maureen E. Comfort, Bryan J. Weiner. 1998. Governance in publicprivate community health partnerships: A survey of the Community Care Network: SM demonstration sites. Nonprofit Management \& Leadership 8:231-332.

2. Ansell, Chris \& Alison Gash. 2007. "Collaborative Governance in theory and practice." Journal of Public Administration Research and Theory. Vol 18. pp 543-571.

3. Aubyn, Miguel St., Alvaro Pina, Filomena Garcia, \& Joana Pais. (2009). Study on the efficiency and effectiveness of public spending on tertiary education. European Economy. Economic Papers 390| November 2009. Technical University of Lisbon: December.

4. Barton J, Stephens J, \& Haslett T (2009) Action research: its foundation in open systems thinking and relationship to the scientific method. Syst Pract Action Res 22:475-488.

5. Beckman S, \& Rosenfield D (2008). Operation Strategy. McGraw-Hill Press.

6. Beierle, Thomas C. 2000. The quality of stakeholder-based decisions: Lessons from the case study record. Discussion Paper 00-56, Resources for the Future.

7. Boyer K K, \& McDermott C (1999). Strategic consensus in operations strategy. J. Oper. Manag. 17:289-305.

8. BPMA-UI, 2007.

9. Bradley, Andrew P. (2016). Talent Management for University. Australian Universities Review, vol. 58, no. 1.

10. Brew, Angela. (2011). Higher Education Research and the Scholarship of Teaching and Learning:The Pursuit of Excellence. International Journal for the Scholarship of Teaching and Learning. Vol. 5, No. 2 (July).

11. Brinkerhoff, Derick W. 1999. Exploring state-civil society collaboration: Policy partnerships in developing countries. Nonprofit and Voluntary Sector Quarterly 28 (Suppl. 1): 59-86.

12. Bryson, John. M, Barbara Crosby, \& Melissa Middleton Stone. 2006. "The design and implementation of cross-sector collaboration: propositions from literature." Public Administrative Review. 66:44.

13. Burger, Joanna, Michael Gochfeld, Charles W. Powers, Lynn Waishwell, Camilla Warren, and Bernard D. Goldstein. 2001. Science, policy, stakeholders, and fish consumption advisories: Developing a fish fact sheet for Savannah River. Environmental Management 27: $501-14$.

14. Catmur, Allison. (2008). The Strategic Social Plan in Labrador: A Case Study in Collaborative Governance. A thesis submitted to the School of Graduate Studies in partial fulfillment of the requirements for the degree of Master of Arts Sociology, Memorial University, St. John's, Newfoundland and Labrador, May 2008.

15. Checkland, P. \& Poulter, J. (2006). Learning for Action, A Short Definitive Account of Soft Systems Methodology and Its Use for Practitioners, Teachers and Students. West Sussex: John Wiley \& Sons, Inc.

16. Checkland, P. \& Scholes, J. (1990). Soft Systems Methodology in Action. New York: John Wiley \& Sons.

17. Checkland, P. (1999). Systems Thinking, Systems Practice, Includes a 30-year retrospective. New York: John Wiley \& Sons, Inc.

18. Checkland, Peter. (1981). Systems Thinking, Systems Practice: Chichester, West Sussex, UK: John Wiley \& Sons. 
19. Cronholm S, \& Goldkuhl G (2003). Understanding the practices of action research. In: The 2nd European conference on research methods in business and management (ECRM 2003), Reading, 20-21 March 2003.

20. Edelenbos, Jurian. 2005. Institutional implications of interactive governance: Insights from Dutch practice. Governance: An International Journal of Policy, Administration and Institutions 18:111-34.

21. Emerson, Kirk; Nabatchi, Tina; \& Balogh, Stephen. 2011. An Integrative Framework for Collaborative Governance. Journal of Public Administration Research and Theory Advance Access 2 May 2011.

22. Eppel, Elizabeth. 2013. Collaborative Governance: Framing New Zealand Practice. Institute for Governance and Policy Studies Working Paper 13/02, April.

23. Flood RL, \& Jackson MC (1991) Creative problem solving: total systems intervention. Wiley, Baffins Lane.

24. Gilliam, Aisha, David Davis, Tracey Barrington, Romel Lacson, Gary Uhl, and Ursula Phoenix. 2002. The value of engaging stakeholders in planning and implementing evaluations. AIDS Education and Prevention 14 (Suppl. A): 5-17.

25. Glasbergen, Pieter, and Peter P. J. Driessen. 2005. Interactive planning of infrastructure: The changing role of Dutch project management. Environment and Planning C: Government and Policy 23: 263-77.

26. Gray, Barbara. 1989. Collaborating: Finding common ground for multi-party problems. San Francisco, CA: Jossey-Bass.

27. Hardjosoekarto $S(2012 b)$ Construction of social development index as a theoretical research practice in action research by using soft systems methodology. Syst Pract Action Res 25(6):493-509. doi:10.1007/ s11213-012-9237-9.

28. Hardjosoekarto S (2013) Dual imperatives of action research: lessons from theoretical research practice to construct social development index by using soft systems methodology. Human Resource Management Research, Scientific and Academic Publishing, pp 49-53. doi:10.5923/j.hrmr.20130301.10.

29. Hardjosoekarto, S \& Yovani, N \& Santiar, L. (2013). Institutional Strengthening for the Role of Mass Media in Disaster Risk Reduction in Japan and Indonesia: An Application of SSM-Based Action Research. Syst Pract Action Res DOI 10.1007/s11213-013-9282-z. Hardjosoekarto, S. (2012a). Soft Systems Methodology (Metode Serba Sistem Lunak). Jakarta: Penerbit Universitas Indonesia dan LabSosio Pusat Kajian Sosiologi.

30. Hayes RH, \&Wheelwright SC (1984). Restoring Our Competitive Edge: Competing Through Manufacturing. John Wiley and Sons. New York.

31. Healey, Mick. (2000). Developing the Scholarship of Teaching in Higher Education: a discipline-based approach. Higher Education Research \& Development. Vol. 19, No. 2, 2000.

32. Heikkila, Tanya, and Andrea K. Gerlak. 2005. The formation of large-scale collaborative resource management institutions: Clarifying the roles of stakeholders, science, and institutions. Policy Studies Journal 33:583-612.

33. Henderson JC, Venkatramen N (1993). Strategic Alignment: leveraging Information Technology for Transforming Organizations. IBM Syst. J. 32(1):4-16.

34. Hill C (1988). Differentiation vs.low cost or differentiation and low cost:A contingency framework. Acad. Manag. Rev. 3(3):401-412.

35. Hossler, Don; Mary Ziskin, Sooyeon Kim, Osman Cekic, \& Jacob P. K. Gross. (2008). in Sandy Baum, Michael McPherson \& Patricia Steele, Editors, What Do We Know About the Impact of Grants to College Students?The Effectiveness of Student Aid Policies: What the Research Tells Us. 2008. Lumina Foundation for Education.

36. Huxham \& Vangen. 2003. Enacting Leadership for Collaborative Advantage: Dilemmas of Ideology and Pragmatism in the Activities of Partnership Managers. British Journal of Management, Vol. 14, S61-S76.

37. Huxham, Chris. 2003. Theorizing collaboration practice. Public Management Review 5:401-23. 
38. Imperial, Mark T. 2005. "Using Collaboration as a Governance Strategy: Lessons from Six Watershed Management Programs." Administration and Society 37(3): 281-320.

39. Issel, L. Michele. 2013. Program Theory and Logic Models, CHSC 433. Module 2/Chapter 5 Part 1UIC School of Public Health. http://www.uic.edu/sph/prepare/courses/ chsc433/chsc433mod02ch051.p

40. Kane L, \& Del Mistro R (2003) Changes in transport planning policy: changes in transport planning methodology? Transportation 30:113-131.

41. Kementerian Pendidikan dan Kebudayaan ((Kemendikbud). (2013). Pedoman Beasiswa Pendidikan Pascasarjana Luar Negeri. Direktorat Pendidik dan Tenaga Kependidikan Direktorat Jenderal Pendidikan Tinggi. Jakarta: Kementrian Pendidikan dan Kebudayaan.

42. Kementerian Pendidikan dan Kebudayaan (Kemendikbud). (2013). Pedoman Beasiswa Pendidikan Pascasarjana Luar Negeri. Jakarta: Direktorat Pendidik dan Tenaga Kependidikan Direktorat Jenderal Pendidikan Tinggi, Kementrian Pendidikan dan Kebudayaan.

43. Kementrian Pendidikan dan Kebudayaan. (Kemendikbud) (2010). Rencana Strategis Kementrian Pendidikan dan Kebudayaan 2010-2014. Jakarta: Kementrian Pendidikan dan Kebudayaan.

44. Khan, Muhammad Ehsan. 2015. Program Governance. CRC Press Taylor \& Francis Group, Boca Raton, Florida, USA.

45. Lasker, Roz D., and Elisa S. Weiss. 2003. Broadening participation in community problem-solving: A multidisciplinary model to support collaborative practice and research. Journal of Urban Health: Bulletin of the New York Academy of Medicine 80:14-60.

46. Lynn, Lawrence E., Carolyn J. Heinrich, and Carolyn J. Hill. 2001. Improving governance: A new logic for empirical research. Washington, DC: Georgetown Univ. Press.

47. Manring, Susan L., and Sam Pearsall. 2004. Creating an adaptive ecosystem management network among stakeholders of the Lower Roanoke River, North Carolina, USA. Ecology and Society 10 (2): 16. http://www.ecologyandsociety.org/vol10/iss2/art16.

48. Margerum, Richard D. 2002. Collaborative planning: Building consensus and building a distinct model for practice. Journal of Planning Education and Research 21:237-53.

49. McKay, J. \& P. Marshall. (2001). The dual imperatives of action research. Information Technology \& People. Vol. 14 No. 1, 2001, pp. 46-59.

50. McLaughlin, John A., \& Gretchen B. Jordan. (2010). Using Logic Model, in, Wholey, Joseph S., Harry P. Hatry, \& Kathryn E. Newcomer (Editors). Third Edition. Handbook of Practical Program Evaluation, Jossey-Bass. A Wiley Imprint, San Francisco:USA.

51. Medica, Karen. (2010). International Students - Understanding the Motives for Higher Education as Development Aid. ISANA. Australia.

52. Morse, R. S. \& Stephens, J. B. (2012). Teaching Collaborative Governance: Phases, Competencies, and Case-Based Learning. Journal of Public Affairs Education, Vol. 18, No. 3, pp. 565-583

53. Munns, A..K. \& B F Bjeirmi. (1996). The role of project management in achieving project success. International Journal of Project Management. Vol. 14 No. 2 pp. 81-87.

54. Murdock, Barbara, Carol Wiessner, and Ken Sexton. 2005. Stakeholder participation in voluntary environmental agreements: Analysis of 10 Project XL case studies. Science, Technology \& Human Values 30:223-50.

55. Nee, Victor. (2005). The New Institutionalism in Economic Sociology. in "The Handbook of Economic Sociology, pp.49-74". New York: Princeton University Press.

56. O'Flynn, J. \& Wanna, J. (2008). Collaborative Governance A new era of public policy in Australia. Canberra: ANU Press.

57. Osborne, David \& Gabler, Ted. 1999. Mewirausahakan Birokrasi, Reinventing Government, Mentransformasi Semangat Wirausaha ke dalam Sektor Publik. Jakarta: Pustaka Binawan Pussindo.

58. Peraturan Menteri Pendidikan Nasional Nomor 42 Tahun 2007 tentang Sertifikasi Dosen.

59. Peraturan Menteri Pendidikan Nasional Republik Indonesia, Nomor 48 Tahun 2009, tentang Pedoman Pemberian Tugas Belajar bagi Pegawai Negeri Sipil di Lingkungan Departemen Pendidikan Nasional. 
60. Peraturan Pemerintah Nomor 37 Tahun 2009 tentang Dosen.

61. Plummer, Ryan, and John Fitzgibbon. 2004. Co-management of natural resources: A proposed framework. Environmental Management 33:876-85.

62. Porter ME (1996). What is Strategy? Harv. Bus. Rev. 74(6):61-78.

63. Rencana Pembangunan Jangka Menengah Nasional Republik Indonesia 2015-2019

64. Rencana Pembangunan Jangka Panjang Republik Indonesia 2005-2025

65. Riccio, S. (2010). Talent Management in Higher Education: Developing Emerging Leaders Within the Administration at Private Colleges and Universities. Lincoln: University of Nebraska, Educational Administration: Theses, Dissertations, and Student Research.

Roberston, John, and Michael J. Lawes. 2005. User perceptions of conservation and participatory management of iGxalingenwa Forest, South Africa. Environmental Conservation 32:64-75.

66. Rogers, Todd, Beth Howard-Pitney, Ellen C. Feighery, David G. Altman, Jerry M. Endres, and April G. Roeseler. 1993. Characteristics and participant perceptions of tobacco control coalitions in California. Health Education Research, Theory \& Practice 8:345-57.

67. Roussos, Stergios Tsai, and Stephen B. Fawcett. 2000. A review of collaborative partnerships as a strategy for improving community health. Annual Review of Public Health 21:269-402.

68. Salimian, H; Khalili, S; Nazemi, J \& Alborzi, M. (2012). Alignment in the organization's strategy window (concentration on business strategy and operations strategy). African Journal of Business Management Vol. 6(51), pp. 12016-12022.

69. Schneider, Mark, John Scholz, Mark Lubell, Denisa Mindruta, and Matthew Edwardsen. 2003. Building consensual institutions: Networks and the national estuary program. American Journal of Political Science 47:143-58.

70. Senge, P.M. (1990). The fifth discipline: The art and practice of the learning organization. New York: Doubleday.

71. Skinner W (1974). The focused factory. Harv. Bus. Rev. 52(3):113-121.

72. Sterman, J. D. (2000). Business Dynamics, Systems Thinking and Modeling for a Complex World. Boston: Irwin McGraw-Hill.

73. Stoker, Gerry. 2004. Designing institutions for governance in complex environments: Normative rational choice and cultural institutional theories explored and contrasted. Economic and Social Research Council Fellowship Paper No. 1.

74. Susanto, Heru., A. Subekti, D. Santoso, \& S.Rustad, (2013). Scientific publication of Indonesian Higher Education: Unraveling the causes of current low achievement and their implication for government policy making. Jakarta:Directorate General of Higher Education.

75. Susskind, Lawrence, and Jeffrey Cruikshank. 1987. Breaking the impasse: Consensual approaches to resolving public disputes. New York: Basic Books.

76. Tett, Lynn, Jim Crowther, and Paul O'Hara. 2003. Collaborative partnerships in community education. Journal of Education Policy 18:37-51.

77. Tompkins, Emma L., and W. Neil Adger. 2004. Does adaptive management of natural resources enhance resilience to climate change? Ecology and Society 9 (2): 10. http://www.ecologyandsociety.org/vol9/iss2/art10 (accessed October 31, 2007).

78. Turner, Y. and S. Robson (2008). Internationalizing the university. London ; New York, Continuum.

79. Uchiyama, Kenichi (2009). Concise Theoretical Grounding of Action Research: Based on Checkland's Soft Systems Methodology and Kimura's Phenomenological Psychiatry. Daito Bunka University, Japan.

80. Undang-Undang Nomor 14 Tahun 2005 tentang Guru dan Dosen.

81. Undang-Undang Nomor 20 Tahun 2003 tentang Sistem Pendidikan Nasional.

82. Vangen, Siv, and Chris Huxham. 2003. Nurturing collaborative relations: Building trust in interorganizational collaboration. Journal of Applied Behavioral Science 39:5-31.

83. Venkatraman $N$ (1989). The concept of fit in strategy research: towards verbal and statistical correspondence. Acad. Manag. Rev. 14(3):423-444. 
84. Venkatraman N, \& Remanujam V (1986). Measuring of Business Performance in Strategy Research: Comparison Approaches. Acad. Manag. Rev. 11:801-814.

85. Voss CA (2005). Paradigms of manufacturing strategy re-visited. Int. J. Oper. Prod. Manag. 25(12):1223-1227.

86. Waage, S. A. 2001. (Re)claiming space and place through collaborative planning in rural Oregon. Political Geography 20:839-57.

87. Walter, Uta, and Christopher Petr. 2000. A template for family centered interagency collaboration. Families in Society: The Journal of Contemporary Human Services 81:494-503.

88. Weech-Maldonado, Robert, and Sonya Merrill. 2000. Building partnerships with the community: Lessons from the Camden Health Improvement Learning Collaborative. Journal of Healthcare Management 45:189-205.

89. Wilson B (1990) Systems: concepts, methodologies and application. Wiley, Chichester.

90. Wondolleck, Julia M., and Steven L. Yaffee. 2000. Making collaboration work: Lessons from innovation in natural resource management. Washington, DC: Island Press.

91. Yong-duck, Jung, Mazmanian, Daniel \& Tang, Shui-Yan. 2009. Collaborative Governance in the United States and Korea: Cases in Negotiated Policymaking and Service Delivery. University of Southern California, WP-April-1. 